\title{
Two New Bioactive Biphenylpropanoids from the Roots of Salsola imbricata (Chenopodiaceae) Growing in Saudi Arabia
}

\author{
MOHAMED HABIB OUESLATI ${ }^{1,2 *}$, JALLOUL BOUAJILA ${ }^{3}$ and HICHEM BEN JANNET ${ }^{4}$
}

\author{
${ }^{1}$ Northern Border University, College of Science, Department of Chemistry , \\ P.O. Box 1231, Arar 91431, Kingdom of Saudi Arabia. \\ ${ }^{2}$ Carthage University, Department of Chemistry, Preparatory Institute for Scientific \\ and Technical Studies, P.O. Box 51, La Marsa 2070, Tunisia. \\ ${ }^{3}$ Laboratoire des IMRCP UMR CNRS 5623, Faculté de Pharmacie de Toulouse, Université \\ de Toulouse, Université Paul-Sabatier, 118 Route de Narbonne, Toulouse F-31062, France. \\ ${ }^{4}$ Laboratoire de Chimie hétérocyclique, Produits Naturels et Réactivité Faculté des \\ Sciences de Monastir, Université de Monastir, Monastir 5019, Tunisia. \\ ${ }^{*}$ Corresponding author E-mail address: oueshabib @ yahoo.fr (M. H. Oueslati)
}

http://dx.doi.org/10.13005/ojc/330432

(Received: May 18, 2017; Accepted: JuLY 12, 2017)

\begin{abstract}
Phytochemical investigation of the roots of Salsola imbricata allowed to two new bioactive biphenylpropanoids (1) and (2) named, biphenylsalsonoid A and B, respectively. Their structures were established through spectroscopic methods (1D and 2D NMR, (ES)-HRMS, and IR). The isolates were tested for their antioxidant activity using DPPH• and ABTS $\bullet+$ assays. 1 and 2 showed a moderate activity towards $\mathrm{DPPH}\left(\mathrm{IC}_{50}=86.5 \pm 1.3\right.$ and $122.3 \pm 0.63 \mu \mathrm{g} / \mathrm{mL}$, respectively $)$ and $\mathrm{ABTS}$ $\left(\mathrm{IC}_{50}=95 \pm 1.5,137.7 \pm 1.2 \mu \mathrm{g} / \mathrm{mL}\right.$, respectively). The antibacterial effect of the ethyl acetate extract and the isolates were assessed. Results obtained revealed that compounds showed important antibacterial activities against S. aureus, S. epidermidis, M. luteus, and E. coli with MIC values ranging from 16 to $32 \mu \mathrm{g} / \mathrm{mL}$.
\end{abstract}

Keywords: Salsola imbricata, biphenylsalsonoids, NMR, antioxidant activities, antibacterial activities.

\section{INTRODUCTION}

The genus Salsola includes halophyte species and belongs to the family of Chenopodiaceae $e^{1-3}$. The genus is widespread in the dry regions of Middle
East, Africa, and Europe. Many species among the genus are used in traditional medicine. In the Middle East, Salsola baryosma is used as a diuretic agent and against some inflammations ${ }^{4}$. This plant also exhibits antioxidant activities ${ }^{5}$, alkaloids (salsolin 
and salsolidin) have been isolated from Salsola tragus (synonym: Salsola kali) used in the treatment of hypertension by stimulating the activity of sleep ${ }^{6,7}$. At present, only few species of the genus have been studied chemically and biologically and were found to be a good source of phenolic compounds identified in S. kali, S. soda, S. oppositifolia and S. collina ${ }^{8,9}$. Furthermore, antioxidant triterpenes were isolated from $S$. baryosma and $S$. somalensis ${ }^{10}$ and new antioxidant bibenzyl derivative and isoflavonoid were isolated from $S$. tetrandra ${ }^{11}$. Our previous work on the genus led to salsolanol and biphenylsalsinol isolation from S. villosa ${ }^{12}$ and cleomiscosin D, norisoprenoid, long-chain hydroxyl fatty acids, taxiphyllin, trans- $N$ feruloyltyramine $S$-(-)-trans- $N$-feruloyloctopamine and coumarinolignan from $S$. tetrandra ${ }^{13,14}$. Recent research on Salsola imbricata showed the presence of triterpene saponins from the methanolic extract of roots ${ }^{14}$ and new isorhamnetin derivatives from the leaves ${ }^{15}$. Thus, in order to continue our research on the genus of salsola growing in Saudi Arabia. We focused our study on the ethyl acetate extract from the roots of $S$. imbricata because it has not been studied previously. Indeed, the present study suggests isolating new compounds with important biological activities. We try to the isolation of new bioactive compounds from the roots of $S$. imbricate and the evaluation of its antibacterial activity against Gram-positive and Gram-negative bacteria. Furthermore, the in vitro antioxidant activity was tested by using DPPH• and ABTS $\bullet^{+}$assays of isolated compounds.

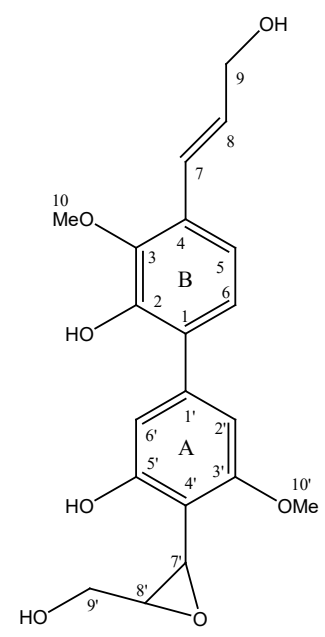

Compound 1

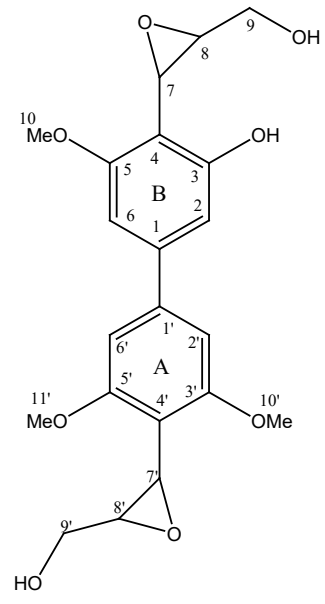

Compound 2
Fig. 1: Structure of compounds 1 and 2

\section{MATERIALS AND METHODS}

\section{General Procedures}

The optical rotations were recorded on a Perkin-Elmer 241-MC polarimeter. UV spectra were measured by using a Shimadzu UV-2401A spectrophotometer. Infra-red spectra were measured on a Perkin-Elmer 157G. ${ }^{1} \mathrm{H},{ }^{13} \mathrm{C}$ and 2D NMR spectra of isolated 1 and 2 were obtained in $\mathrm{CD}_{3} \mathrm{OD}$ on Bruker $300 \mathrm{MHz}, 75 \mathrm{MHz}$ ( spectrometer using internal reference the residual solvent resonance. Coupling constants were measured in Hertz and chemical shifts were reported in ppm. ESI-HRMS was measured on a Shimadzu LC-MS Spectrometer.

\section{Plant material}

Roots of Salsola imbricata Delile. ex Schul. Were collected from Arar, Saudi Arabia, on November 2015. The plant was identified by Dr. Ahmed K. Osman, College of Sciences, Department of Biology, Kingdom of Saudi Arabia and deposited in the herbarium (Sv-26) of the above department.

\section{Extraction and Isolation}

The roots from $S$. imbricata were dried and then ground into powder. $1 \mathrm{Kg}$ of powder was extracted with methanol (5L). After that the crude extract was evaporated in vacuo yielding a residue of $65.4 \mathrm{~g}(\%)$. The residue was dissolved in water $(2 \mathrm{~L})$ and then extracted successively with petroleum ether, ethyl acetate and $n$-butanol yielding 12.4, 16.2 and $24.6 \mathrm{~g}$ sub-extracts, respectively. The ethyl acetate extract was fractionated on a column chromatography (silica gel- mesh 70-230, $70 \times 5$ $\mathrm{cm}$, i.d.) eluted with mobile phase of $\mathrm{n}$-hexane/ EtOAc (100:0, 90:10, 80:20, 70:30, 60:40, 50:50, $40: 60,30: 70,20: 80,10: 90,0: 100,1 \mathrm{~L}$ each) and EtOAc/MeOH (90/10 80:20, 70:30, 60:40, 50:50, $500 \mathrm{~mL}$ each ). After TLC monitoring the column chromatographic fractions were combined into eight fractions $\left(F_{1}-F_{8}\right)$. Fraction $F_{4}(426 \mathrm{mg})$ was separated on a silica gel column (mesh 70-230, $70 \times 2 \mathrm{~cm}$, i.d) that was eluted with $\mathrm{CHCl}_{3} / \mathrm{MeOH}(100: 0$ to $60: 40)$ to obtained four subfractions $\left(A_{1}\right.$ to $\left.A_{4}\right)$. The purification of the fraction of the subfraction $A_{2}(62 \mathrm{mg})$ by using preparative TLC 85:15 $\left(\mathrm{CHCl}_{3} / \mathrm{MeOH}\right)$ to yield $16 \mathrm{mg}$ of 1 and $12 \mathrm{mg}$ of 2 .

\section{Antibacterial Activities}

The antibacterial activities were tested against Gram-positive (Staphylococcus aureus, $S$. epidermidis and Micrococcus luteus) and Gramnegative strains (Pseudomonas aeruginosa, 
Escherichia coli, and Salmonella typhimurium). The tested extracts were respectively: Methanol crude of the roots, the isolated compound $\mathbf{1}$ and the isolated compound 2. Mueller-Hinton agar $(5 \mathrm{ml})$ was used for the culture of bacteria (stored at $-70{ }^{\circ} \mathrm{C}$ stock) and the media were incubated for $24 \mathrm{~h}$ at $37^{\circ} \mathrm{C}$.

The antibacterial activity was evaluated by minimum inhibitory concentration (MIC) $)^{16,17}$. Serial tube dilution was used to determine the values of MIC for the methanol crude extract and for the two isolated compounds. To obtain stock solution, $0.5 \mathrm{mg}$ of plant extracts (methanol crude, compound 1 and 2) was suspended in $2 \mathrm{~mL}$ of distilled water and 2 drops of between- 80 for the homogenization. The suspensions of micro-organisms consist of a medium with the concentration fixed at $10^{7}$ organisms $/ \mathrm{mL}$ and one drop of suspension $(0.02 \mathrm{~mL})$ was added to the broth dilution. The temperature of the incubation was fixed at $37^{\circ} \mathrm{C}$ for $18 \mathrm{~h}$ and the tubes were examined for the growth. The MIC of the tested extract/products was fixed for the lowest concentration that showed the totally absence of the growth for the microorganisms. The negative and the positive control consist, respectively, of distilled water with 2 drops of tween-80 and kanamycin.

\section{Antioxidant activities}

Free radical scavenging ability using $\mathrm{DPPH}^{\circ}$ radical

The protocol was used as described, previously, by Tepe, B. et al. $2005^{19}$. Briefly, $2 \mathrm{~mL}$ of DPPH solution (100 ìg/mL, EtOH) was added to $0.5 \mathrm{~mL}$ of compounds $(0.01-1 \mathrm{mg} / \mathrm{mL})$. After 30 $\mathrm{min}$, the absorbance was read at $517 \mathrm{~nm}$. The blank consists of $2 \mathrm{~mL}$ of DPPH solution and $0.5 \mathrm{~mL}$ of methanol. The $\mathrm{IC}_{50}$ was determined by the following equation:

\%Inhibition $\left.=\left[\left(A_{\text {blank }}-A_{\text {sample }}\right) / A_{\text {blank }}\right)\right] \times 100$

$A_{\text {blank }}$ and $A_{\text {sample }}$ were, respectively, the absorbance values of the control and the test sample. Vitamin $\mathrm{C}$ was used as reference and tests were measured in triplicate.

\section{Free radical scavenging ability using $\mathrm{ABTS}^{\circ+}$ radical cation}

ABTS was dissolved in distilled water and the concentration was fixed at $7 \mathrm{mmol} / \mathrm{L}^{20}$. For the completion of radical generation, $\mathrm{ABTS} \bullet \%+$ radical cation was generated by adding the potassium persulfate $(2.45 \mathrm{mmol} / \mathrm{L})$ to the ABTS solution. The mixture was conserved in the darkness for 12-16 $\mathrm{h}$ at room temperature. After a dilution of the mixture with ethanol, the wavelength was fixed at $734 \mathrm{~nm}$ until to obtain an absorbance value of $0.70 \pm 0.02$. ABTS solution $(50 \mathrm{~mL})$ was added to $950 \mathrm{~mL}$ of compounds $(0.01-1 \mathrm{mg} / \mathrm{mL})$ and after $6 \mathrm{~min}$. the absorbance was measured at $734 \mathrm{~nm}$. The blank consists of $50 \mathrm{~mL}$ of ABTS solution and $950 \mathrm{~mL}$ of ethanol. The $I_{50}$ was determined by the formula mentioned before in DPPH assays.

Compound 1 (Fig. 1) has a molecular formula of $\mathrm{C}_{20} \mathrm{H}_{22} \mathrm{O}_{7}$ as deducted from the ESI-HRMS $\left(\mathrm{m} / \mathrm{z}=\mathrm{m} / \mathrm{z} 397.1260[\mathrm{M}+\mathrm{Na}]^{+}\right)$. The IR spectrum revealed the presence of hydroxyl group $\left(3446 \mathrm{~cm}^{-1}\right)$ and aromatic ring $\left(1625 \mathrm{~cm}^{-1}\right)$.

In the aromatic region of the spectrum ${ }^{1} \mathrm{H}$ NMR of 1 (Table 1) displayed proton signals at $\delta_{\mathrm{H}} 6.98(\mathrm{H}-2, \mathrm{~d}, J=1.9 \mathrm{~Hz})$ and 6.84 $(\mathrm{H}-6, \mathrm{~d}, J=1.9 \mathrm{~Hz})$, attributable to the metacoupled protons, of the terasubstituted aromatic ring $A$ and two aromatic proton signals at $\delta_{H} 7.01$ $(\mathrm{H}-5, \mathrm{~d}, J=8.1 \mathrm{~Hz})$ and $6.78(\mathrm{H}-6, \mathrm{~d}, J=8.1 \mathrm{~Hz})$ attributable to the two ortho-coupled protons of the tetrasubstituted aromatic ring $B$. The same spectrum displayed the presence of two trans-olefinic protons resonating at $\delta_{\mathrm{H}} 5.55(1 \mathrm{H}, \mathrm{d}, J=15.9 \mathrm{~Hz})$ and at $\delta_{\mathrm{H}}$ $6.25(1 \mathrm{H}, \mathrm{dt}, J=15.9 \mathrm{~Hz}, J=6.0 \mathrm{~Hz})$, attributable to $\mathrm{H}-7$ and $\mathrm{H}-8$, respectively, as well as two methoxy groups at $\delta_{\mathrm{H}} 3.76(3 \mathrm{H}, \mathrm{s})$ and $3.84(3 \mathrm{H}, \mathrm{s})$ assignable to $\mathrm{H}-10$ and $\mathrm{H}-10$, respectively.

The ${ }^{13} \mathrm{C}-\mathrm{NMR}$ and DEPT spectra of 1 showed signals for $14 s p^{2}$ carbons (seven methines and seven quaternary carbons) and $6 s p^{3}$ carbons (two methyl, two methylene and two methine groups) (Table 1).

The full analysis of the ${ }^{1} \mathrm{H}$ and ${ }^{13} \mathrm{C}$ NMR spectra were obtained by using $2 \mathrm{D}$ NMR. The correlations observed in the ${ }^{1} \mathrm{H}-{ }^{1} \mathrm{H}$ COSY spectrum between the olefinic protons $(\mathrm{H}-7$ and $\mathrm{H}-8)$ and the hydroxymethylenic protons $(\mathrm{H}-9)$ provided evidence for the propenol moiety $\left(-\mathrm{CH}=\mathrm{CH}-\mathrm{CH}_{2} \mathrm{OH}\right)$. The ${ }^{2} \mathrm{~J}$ and ${ }^{3} \mathrm{~J}$ correlation of the olefinic proton $\mathrm{H}-7\left(\delta_{\mathrm{H}}\right.$ $6.25)$ with $\mathrm{C}-3\left(\delta_{C} 151.2\right), \mathrm{C}-4\left(\delta_{C} 126.4\right)$, and C-5 
$\left(\delta_{C} 112.5\right)$ revealed in the HMBC spectrum (Fig. 2) showed that the propenol moiety is connected to the ring $\mathrm{B}$ at $\mathrm{C}-4$ (Fig. 2). This position was consolidated by the appearance of the noe $\mathrm{H}-7 / \mathrm{H}-10(\mathrm{OMe})$. The detection of signals at $\delta_{\mathrm{H}} / \delta_{\mathrm{C}} 5.52 / 87.7$ and 3.42 / 56.3 suggested the presence of a 1,2disubstituted epoxide in the molecule ${ }^{12,21,22}$. The correlations $\mathrm{H}-7^{\prime} / \mathrm{H}_{-} \mathbf{8}^{\prime}$ and $\mathrm{H}-8^{\prime} / \mathrm{H}-9^{\prime}$ observed in ${ }^{1} \mathrm{H}-{ }^{1} \mathrm{H}$ COSY spectrum (Fig. 2) indicated an epoxy substituted propanoid moiety. HMBC cross-peaks of C-4' $\left(\delta_{C} 126.3\right), C-3 '\left(\delta_{C} 149.5\right)$, and C-5' $\left(\delta_{C} 150.1\right)$ with $\mathrm{H}-7^{\prime}\left(\delta_{\mathrm{H}} 5.52\right)$ confirmed the attachment of this epoxy propanoid moiety to the trisubstituted aromatic ring A at C-4' (Fig. 2). This result was consolidated by the neo between $\mathrm{H}-7$ ' and methoxy $\mathrm{H}-10$ ' revealed in the NOESY spectrum (Fig. 2). The biphenylic structure of compound ${ }^{23-24}$ and the connection of two ring $\mathrm{A}$ and $\mathrm{B}$ at $\mathrm{C}-1$ and $\mathrm{C}-1$ ' were evidenced by the ' $\mathrm{J}$ correlations $\mathrm{H}-6 / \mathrm{C}-1$ ' and $\mathrm{H}-2$ '/C-1 observed in $\mathrm{HMBC}$ spectrum (Fig. 2). The position of the two methoxy groups was confirmed by the ${ }^{3} \mathrm{~J}$ correlations $\mathrm{H}-10$ (OMe)/C-3 and $\mathrm{H}-10$ '(OMe)/C-3' in the HMBC spectrum (Fig. 2) and by the appearance of the noe cross peaks $\mathrm{H}-7 / \mathrm{H}-10(\mathrm{OMe})$ and $\mathrm{H}-7^{\prime} / \mathrm{H}-10^{\prime}(\mathrm{OMe})$ in the NOESY spectrum. The above data, were found to be consistent with a new biphenylpropanoid structure identified to be 4'-(9'- (hydroxymethyl) oxiran-7'-yl)4-((E)-3-hydroxyprop-7-en-7-yl)-3,3'-dimethoxy-[1,1'biphenyl]-2,5'-diol named biphenylsalsonoid $\mathbf{A}$

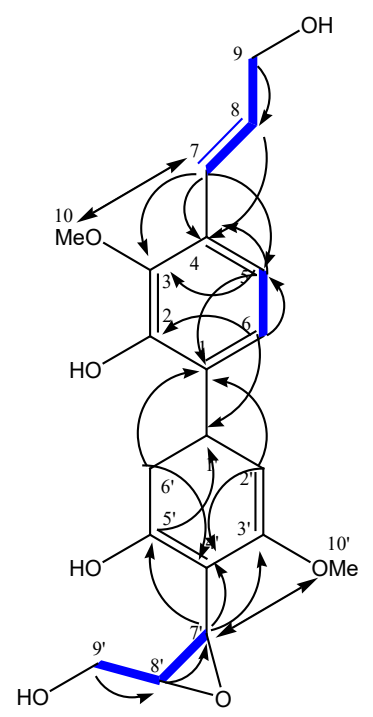

Fig. 2: Relevant HMBC ( CosY), cos and NOEs $(-)$ ) correlations for compound 1
Compound 2 Fig. 1 has a molecular formula of $\mathrm{C}_{21} \mathrm{H}_{24} \mathrm{O}_{8}$ as deducted from the ESI-HRMS ( $\mathrm{m} / \mathrm{z}=$ $\left.\mathrm{m} / \mathrm{z} 427.1365[\mathrm{M}+\mathrm{Na}]^{+}\right)$. The IR spectrum revealed the presence of hydroxyl group $\left(3448 \mathrm{~cm}^{-1}\right)$ and aromatic ring $\left(1622 \mathrm{~cm}^{-1}\right)$.

The aromatic region of the ${ }^{1} \mathrm{H}-\mathrm{NMR} 2$ (table 1) spectrum showed characteristic singlets at $\delta_{\mathrm{H}} 6.58(2 \mathrm{H}, \mathrm{s})$ which were attributed to the equivalent protons $\mathrm{H}-2$ ' and $\mathrm{H}-6$ ' of the tetrasubstituted aromatic ring $A$. The same region exhibited two aromatic signals at $\delta_{H} 6.87(\mathrm{~d}, J=1.8 \mathrm{~Hz})$ and at $\delta_{H} 7.01(\mathrm{~d}, J$ $=1.8 \mathrm{~Hz}$ ) attributed to $\mathrm{H}-2$ and $\mathrm{H}-6$. In addition, the spectrum showed a singletat $\delta_{\mathrm{H}} 3.78(6 \mathrm{H}, \mathrm{s})$ attributed to the two equivalent methoxy goups $\mathrm{H}-10$ 'and $\mathrm{H}-11$ ' $\left(-\mathrm{OCH}_{3}\right)$ attached to the aromatic ring $\mathrm{A}$ and another singlet at $\delta_{\mathrm{H}} 3.76(3 \mathrm{H}, \mathrm{s})$ corresponding to the methoxy group $\mathrm{H}-10\left(-\mathrm{OCH}_{3}\right)$ attached to the second aromatic ring $\mathrm{B}$. The ${ }^{1} \mathrm{H}-\mathrm{NMR},{ }^{13} \mathrm{C}-\mathrm{NMR}$ and $\mathrm{HMQC}$ spectra exhibited characteristic resonances of two disubstituted epoxides ${ }^{12,21,22}$. at $\delta_{\mathrm{H}} / \delta_{\mathrm{C}} 5.51(\mathrm{H}-7, \mathrm{~m}) /$ 87.3 (C-7), 3.42 (H-8, m)/ 56.2 (C-8), $5.46\left(\mathrm{H}-7^{\prime}, \mathrm{m}\right) /$ 87.1(C-7') and $3.40(\mathrm{H}-8$ ', $\mathrm{m}) / 56.0\left(\mathrm{C}-8^{\prime}\right)$.

The ${ }^{13} \mathrm{C}$ spectrum of 2 showed resonance of $12 s p^{2}$ carbons attributable to eight quaternary carbons which four are oxygenated and four tertiary carbons (Table 1). The same spectrum also showed three methoxy carbons at $\delta_{\mathrm{C}} 56.8$ and six

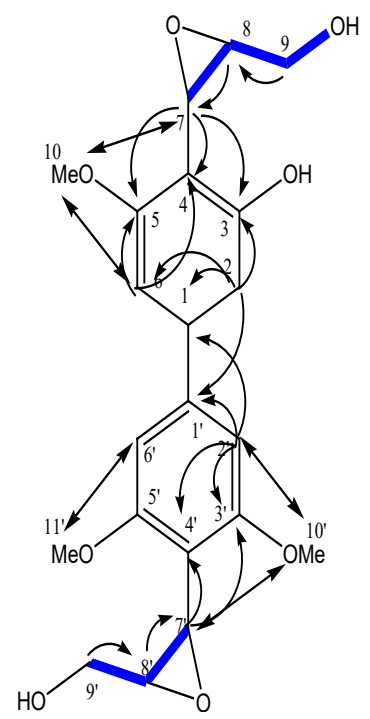

Fig. 3: Relevant HMBC ( ) , COSY ( ) and NOEs $(\rightarrow-)$ correlations for compound 2 
$s p^{3}$ oxygenated carbons in the region $\delta_{C} 56.0-87.3$ (Table 1).

The ${ }^{1} \mathrm{H}-{ }^{1} \mathrm{H}$ COSY experiment (Fig. 3) showed correlations $\mathrm{H}-8$ with $\mathrm{H}-7$ and $\mathrm{H}-9$ on the one hand and $/ \mathrm{H}-8$ ' with $\mathrm{H}-7$ 'and $\mathrm{H}-9$ 'on the other hand provided evidence for the two epoxy propanoid moieties. The above spectral data indicate that $\mathbf{2}$ and $\mathbf{1}$ are two analogous compounds.

The HMBC long-range ${ }^{2} J$ and ${ }^{3} J$ correlations $\mathrm{H}-2$ with $\mathrm{C}-1, \mathrm{C}-3$ and $\mathrm{C}-6$; $\mathrm{H}-6$ with $\mathrm{C}-4$; and $\mathrm{H}-2$ with $\mathrm{C}-1, \mathrm{C}-3$ ' and $\mathrm{C}-4$ ' indicated 2 should be processed a biphenyl skeleton ${ }^{23,24}$ (Fig. 3). The location of the hydroxyl function, the three methoxy groups and the two epoxy propanoids one the biphenyl skeleton were evidenced by the HMBC and the NOESY experiments. The presence of the first epoxy propanoid at C-4 was established by the correlations of the proton $\mathrm{H}-7\left(\delta_{\mathrm{H}} 5.51\right)$ with $\mathrm{C}-4\left(\delta_{\mathrm{C}}\right.$ 126.8), C-3 (150.1) and C-5 (152.4) observed in $\mathrm{HMBC}$ spectrum. The location of the methoxy group at $\mathrm{C}-5$ was confirmed by the ${ }^{3} \mathrm{~J}$ correlations $\mathrm{H}-10 / \mathrm{C}-5$ deduced from the HMBC spectrum (Fig. 3) and by the appearance of the noe between $\mathrm{H}-7$ and $\mathrm{H}-10$ ($\mathrm{OMe}$ ) observed in the NOESY spectrum. The second epoxy propanoid at C-4' was clearly indicated by the correlations of the proton $\mathrm{H}-7^{\prime}\left(\delta_{H} 5.46\right)$ with (C-3'and C-5', $\left.\delta_{C} 152.2\right)$ and C-4' $\left(\delta_{C} 126.2\right)$ observed in HMBC spectrum (fig 3 ). The position of the two equivalent methoxy groups at C-3' and C-5' was established by the ${ }^{3} J_{C-H}$ correlations of the protons resonating at $\delta_{H} 3.78\left(\mathrm{H}-10^{\prime}, 11^{\prime}\right)$ and the aromatic quaternary carbons C-3', C-5' ( $\delta_{C}$ 152.2) (Fig. 3). This result was reinforced by the noe cross peak between the proton $\mathrm{H}-7^{\prime}\left(\delta_{\mathrm{H}}, 5.46\right)$ and the equivalent protons of the two methoxy groups $\mathrm{H}-10$ ' and $\mathrm{H}-11$ ' $\left(\delta_{\mathrm{H}} 3.78\right)$ (Fig. 3). The above data, were found to be consistent with a new biphenylpropanoid structure identified to be 4,4' bis-(9-hydroxymethyl) oxiran-7-yl)-5,3',5'-trimethoxy [1,1'biphenyl]-3-ol named biphenylsalsonoid $\mathbf{B}$.

\section{Antioxidant activities}

For the antioxidant activities of the isolated compounds 1 and 2, two assays have been

Table 1: NMR spectral data of compounds 1 and 2 (CD $\mathrm{OD}_{3}, 300 \mathrm{MHz}, \boldsymbol{J}$ in $\mathrm{Hz}$ )

\begin{tabular}{lllll}
\hline \multicolumn{3}{c}{ Compound 1 } & \multicolumn{2}{l}{ Compound 2 } \\
\hline Position & ${ }^{13} \mathbf{C}(\delta)$ & ${ }^{1} \mathrm{H}(\delta)$ & ${ }^{13} \mathbf{C}(\delta)$ & ${ }^{1} \mathrm{H}(\delta)$ \\
\hline 1 & 139.5 & - & 138.7 & - \\
2 & 149.0 & - & 112.4 & $7.01(1 \mathrm{H}, \mathrm{d}, J=1.8)$ \\
3 & 151.2 & - & 150.1 & - \\
4 & 126.4 & - & 126.8 & - \\
5 & 112.5 & $7.01(1 \mathrm{H}, \mathrm{d}, J=8.1)$ & 152.4 & - \\
6 & 116.7 & $6.78(1 \mathrm{H}, \mathrm{d}, J=8.1)$ & 110.2 & $6.87(1 \mathrm{H}, \mathrm{d}, J=1.8)$ \\
7 & 132.5 & $6.25(1 \mathrm{H}, \mathrm{d}, J=15.9)$ & 87.3 & $5.51(1 \mathrm{H}, \mathrm{m})$ \\
8 & 127.9 & $5.55(1 \mathrm{H}, \mathrm{dt}, J=15.9 \mathrm{~J}=6.0)$ & 56.2 & $3.42(1 \mathrm{H}, \mathrm{m})$ \\
9 & 64.5 & $4.21(2 \mathrm{H}, \mathrm{d}, J=5.7)$ & 64.6 & $4.32(1 \mathrm{H}, \mathrm{m})$ \\
$10(\mathrm{OMe})$ & 56.4 & $3.84(3 \mathrm{H}, \mathrm{s})$ & 57.2 & $3.76(3 \mathrm{H}, \mathrm{s})$ \\
$1^{\prime}$ & 136.0 & - & 138.4 & - \\
$2^{\prime}$ & 113.9 & $6.98(1 \mathrm{H}, \mathrm{d}, J=1.9)$ & 108.6 & $6.58(1 \mathrm{H}, \mathrm{s})$ \\
$3^{\prime}$ & 149.5 & - & 152.2 & - \\
$4^{\prime}$ & 126.3 & - & 126.2 & - \\
$5^{\prime}$ & 150.1 & - & 152.2 & - \\
$6^{\prime}$ & 110.4 & $6.84(1 \mathrm{H}, J=1.8)$ & 108.6 & $6.58(1 \mathrm{H}, \mathrm{s})$ \\
$7^{\prime}$ & 87.4 & $5.52(1 \mathrm{H}, \mathrm{d}, J=6.3)$ & 87.1 & $5.46(1 \mathrm{H}, \mathrm{m})$ \\
$8^{\prime}$ & 56.3 & $3.42(1 \mathrm{H}, \mathrm{m})$ & 56.0 & $3.40(1 \mathrm{H}, \mathrm{m})$ \\
$9^{\prime}$ & 64.3 & $4.31(2 \mathrm{H}, \mathrm{m})$ & 64.4 & $4.32(2 \mathrm{H}, \mathrm{m})$ \\
$1^{\prime}(\mathrm{OMe})$ & 57.2 & $3.76(3 \mathrm{H}, \mathrm{s})$ & 56.8 & $3.78(3 \mathrm{H}, \mathrm{s})$ \\
$11^{\prime}(\mathrm{OMe})$ & - & - & $5.78(3 \mathrm{H}, \mathrm{s})$ \\
\hline
\end{tabular}


Table 2. Antioxidant (DPPH' and ABTS*+ Assays) activities of compounds 1 and 2

\begin{tabular}{llll}
\hline & \multicolumn{3}{c}{ IC $_{50}$ values $(\mu \mathbf{g} / \mathbf{m L})$} \\
\cline { 2 - 4 } & $\mathbf{1}$ & $\mathbf{2}$ & Vitamin C \\
\hline DPPH $\%^{\circ}$ & $86.5 \pm 1.3$ & $122.3 \pm 1.4$ & $26.0 \pm 1.2$ \\
ABTS $\%+^{9}$ & $95.1 \pm 1.5$ & $137.7 \pm 1.2$ & $22.4 \pm 0.5$ \\
\hline
\end{tabular}

According to the results given in Table 3. The compounds 1 and 2 display the same activity against the three Gram-negative used and the Gram-positive strains $S$. aureus and S. epidermidis. This finding could be due to the common biphenyl skeleton bearing in the same position (C-4') present in both 1 and 2. On the other hand, Compound 2 (MIC $=16$ $\mu \mathrm{g} / \mathrm{mL}$ ) was found to be two times more active than compound 1 against $M$. luteus.

Table 3. Antibacterial activities of EtOAc extract and compounds 1 and 2

\begin{tabular}{lllll}
\hline Strains & \multicolumn{4}{c}{ MIC values $(\mu \mathbf{g} / \mathbf{m L})$} \\
\cline { 2 - 5 } & EtOAc Extract & $\mathbf{1}$ & $\mathbf{2}$ & Kanamycin \\
\hline Gram-positive & & 32 & 32 & 2 \\
S. epidermidis & 32 & 16 & 16 & 2 \\
S. aureus & 16 & 32 & 16 & 4 \\
M.s luteus & 16 & & & \\
Gram-negative & & 16 & 16 & 4 \\
E. coli & 16 & 64 & 64 & 8 \\
P. aeruginosa & 64 & 16 & 16 & 4 \\
S. typhimurium & 16 & & & \\
\hline
\end{tabular}

MIC: Minimum inhibitory concentration Kanamycin: antibiotic

assessed: DPPH free radical scavenging and ABTS system (Table 2).

The isolate biphenylpropanoids 1 and 2 showed a moderate antioxidant activity towards DPPH with $\mathrm{IC}_{50}$ values of $86.5 \pm 1.3$ and $122.3 \pm 0.63$ $\mu \mathrm{g} / \mathrm{mL}$, respectively, but less potent when compared to Vitamin C. On the other hand, the isolated biphenylpropanoids showed antioxidant activity against ABTS in the similarly order as against DPPH $\left(\mathrm{IC}_{50}=95 \pm 1.5,137.7 \pm 1.2 \mu \mathrm{g} / \mathrm{mL}\right.$, respectively). Compound 1 has a relatively high activity due to the presence of two phenol groups by comparison with 2 bearing one phenol group.

\section{Antibacterial Activities}

The in vitro antibacterial activity of the EtOAc extract of the roots of $S$. villosa, compounds 1 and compound 2 was assessed using the MIC method against three Gram-positive bacteria; $S$. aureus, $S$. epidermidis and Micrococcus luteus and three Gramnegative bacteria; Escherichia coli, Pseudomonas aeruginosa and Salmonella typhimurium.
This dual sensitivity against the compound 2 might be explained by the difference in structure between the two compounds, mainly the apparition of a new epoxy moiety at C-4 and another methoxy group at $\mathrm{C}-5^{\prime}$. In addition to the modification in the position of the hydroxyl group by comparison to compound 1.

\section{CONCLUSION}

Two new natural biphenylpropanoid analogous 1 and 2 (named biphenylsalsonoids $A$ and B) were isolated from the roots of Salsola villosa. Their structures were elucidated by spectroscopic methods including 1D, 2D-NMR experiments. Compounds 1 and 2 showed a moderate activity of radicalscavenging towards DPPH and ABTS. The ABTS scavenging activity of compounds was similar to the DPPH free radical scavenging. Their antibacterial activity was evaluated by the MIC method against Staphylococcus aureus, S. epidermidis, Micrococcus luteus, Escherichia coli, Salmonella typhimurium and Pseudomonas aeruginosa. The two compounds have 
shown the same activity towards the tested bacteria, except $M$. luteus which exhibited more sensitivity against compound 2 .

\section{ACKNOWLEDGMENTS}

The authors would like to extend their sincere appreciation to the Deanship of Scientific Research at Northern Borders University for its funding of this research through the research project No. SCl-2016-F-5705.

\section{REFERENCES}

1. Botschantzer, V.P.A. synopsis of Salsola (Chenopodiaceae) from South and SouthWest Africa. Kew Bulletin. 1974, 29,597604.

2. Vladimir, I. P.; Elena, V.V.; Alexander, N.K.; Maurice. S.B; Eric, G; Vincent, R. F.; Clanton, C. B.; Gerald, E. E. Occurrence of C3 and C4 photosynthesis in cotyledons and leaves of Salsola species (Chenopodiaceae). Photosynthesis Research. 2000, 63, 69-84.

3. Mabberley, D. J. The plant book. A portable dictionary of the vascular plants (2nd Edition), Cambridge university press, London. 1997, 149, 260

4. Al-Saleh, F.S.; Ali, H.; Mirza, M. Chemical constituents of some medicinal plants growing in Bahrain. Fitoterapia. 1993, 64, 251-256.

5. Borkowski, B.; Wrocinski, T. Porownanie dzialania hipotensy junego salsoliny I salsolidyny oraz protowera lyren. Actal. Polon. Pharm. 1959, 16, 197-203.

6. Tundis, R.; Menichini, F. Confort, F.; Loizzo, M.R.; Bonesi, M.; Statti, G.; Menichini, F.A. potential role of alkaloid extracts from Salsola species (Chenopodiaceae) in the treatment of Alzheimer's disease. J. Enzyme Inhib. Med. Chem. 2009, 24, 818-824.

7. Ahmad, Z.; Mehmood, S.; Fatima, I.; Malik, A.; Ifzal, R.; Afza, N.; Iqbal, L.; Latif, M.; Nizami, T.A. Structural determination of salsolins $A$ and $B$, new antioxidant polyoxygenated triterpenes from Salsola baryosma by 1D and 2D NMR. Spectroscopy. Magn. Reson. Chem. 2008, 46(1), 94-98

8. Syrchina, A.I.; Vereshchagin, A.L.; Larin, M.F.; Semenov, A. Flavonoids of Salsola collina. Compounds Chemistry of Natural. 1989, 25(5), 619-620.
9. Tundis, R.; Loizzo, M.R.; Statti, G.A.; Menichini, F. Inhibitory effects on the digestive enzyme alpha-amylase of three Salsola species (Chenopodiaceae). in vitro Pharmazie. 2007, 62, 473-475. 271

10. Arafa, I.; Hamed, M.M.; Mohamed G.S.; Usama A.; Moatz M.T.; Angela, P.; Sonia, P. Triterpenesaponins from Salsola imbricate. PhytochemistryLetters. 2011, 4, 353-356.

11. Ahlem, B.; Atef Ch.; Hatem G.; M'hamed, A.H.; Hichem, B.J. New antioxidant bibenzyl derivative and isoflavonoid from the Tunisia Salsola tetrandra Folsk. Natural product research. 2012, 26(3), 235-242.

12. Oueslati, M.H.; Al-Ghamdi, F.A.; Noubigh, A. Two new bioactive salsolanol and biphenylsalsinol from the aerial parts of Salsola villosa Delile. ex Schul. (Chenopodiaceae) growing in Saudi Arabia. Asian Pac. J. Trop. Biomed. 2015,5(8), 624-628.

13. Oueslati, M.H.; Ben Jannet, H.; Abreu, P.; Mighri. Z. J. Soc. Alger. Chim. 2004, 14, 181187.

14. Oueslati, M.H; Hichem, B.; Zine, M.; Chriaa, J.; Pedro, M. Phytochemical Constituents from Salsola tetrandra. J. Nat. Prod. 2006, 69, 1366-1369.

15. Osman, S.M.; El Kashak, W.A.; Wink, M.; El Raey, M.A. New isorhamnetin derivatives from Salsola imbricata Forssk. leaves with distinct anti-inflammatory activity. Pharmacognosy magazine. 2016, 12, 47-51.

16. Iwaki, K.; Koya-Miyata; Kohno, K; Ushio, S.; Fukuda, S. Antimicrobial activity of Polygonum tinctorium Lour. extract against oral pathogenic bacteria. Nat. Med. 2006, 53, 72-79.

17. Tripathi, V.D.; Agarwal, S.K.; Rastogi, R.P. An antibacterial biphenyl derivative and 
other constituents of Atylosiatri nervia. Phytochemistry. 1978, 17, 2001-2003.

18. Indu, M.N.; Hatha, A.A.M.; Abirosh, C.; Harsha, U.; Vivekanandan, G. Antimicrobial activity of some of the south-Indian spices against serotypes of Escherichia coli, Salmonella, Listeri amonocytogenes and Aeromonas hydrophila. Braz. J. Microbiol., 2006, 37, 153158.

19. Tepe, B.; Daferera, D.; Sokmen, A.; Sokmen, M.; Polissiou, M. Antimicrobial and antioxidant activities of essential oil and various extracts of Salvia tomentosa Miller (Lamiaceae). Food Chem. 2005, 90, 333-340.

20. Re, R.; Pellegrini, N.; Proteggente, A.; Pannala, A.; Yang, M.; Rice-Evans, C. Antioxidant activity applying an improved ABTS radical cation decolorization assay. Free Radical Bio. Med. 1999, 26, 1231-1237.
21. Wen-Zhe, H.; Chao-Feng, Z.; Mian, Z.; Zheng-Tao, W. A New Biphenylpropanoid from Alpiniakatsumadai. Journal of the Chinese Chemical Society. 2007, 54, 1553-1556.

22. Ribeiro, P.R.; Ferraz, C.G.; Guedes, M.L.S.; Martins, D.; Cruz, F.G. A new biphenyl and antimicrobial activity of extracts and compounds from Clusia burlemarxii. Fitoterapia. 2011, 82, 1237-1240

23. Jun, L.; Yan, H.; Xin-Lan, G.; Jian, L.; ShengPing, D.; Qiang, W.; Yan-Jun, N. Z.; XiaoJia, S.; Rui-Yun, Y. Anti-hepatitis B virus constituents from the stem bark of Streblus asper. Phytochemistry. 2012, 82, 100-109.

24. Siridechakorn, I.; Maneerat, W.; Sripisut, T.; Ritthiwigrom, T.; Cheenpracha, S.; Lapho, O. S. Biphenyl and xanthone derivatives from the twigs of a Garcinia sp. (Clusiaceae). Phytochemisty Letters. 2014, 8, 77-80. 